\title{
Breakfast at Milliways - The didactic challenges of bioethics
}

\author{
Mickey Gjerris, M.T., Ph.D., Assistant Professor, Danish Centre for Bioethics and Risk \\ Assessment, Royal Veterinary and Agricultural University. Rolighedsvej 25, DK-1958 \\ Frederiksberg C, Denmark. Phone+4525370385,Email:mgj@kvl.dk.
}

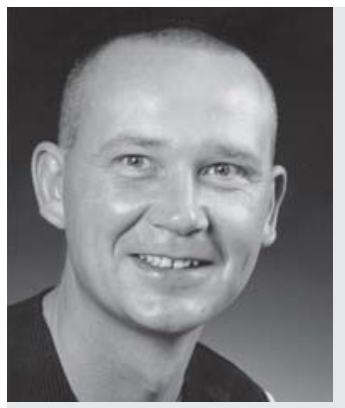

Mickey Gjerris has a master degree in theology from the University of Copenhagen. His ph.d. thesis was a critical reading of K. E. Løgstrup's epistemology and ethics with regards to the ethical aspects of xenotransplantation. Today he works as an assistant professor at The Danish Center for Bioethics and Risk Assessment, teaching Ethics \& Theory of Science and doing research within the areas of bioethics, nano-ethics and ethics of nature.

\begin{abstract}
This article discusses some of the main challenges in doing and teaching bioethics from the perspective of a teacher of the subject. The emphasis is put on the interconnectedness between the methodology of teaching and the general ethical outlook that the teaching seeks to promote. The article is mainly based on practical experiences - and just a twist of phenomenology.
\end{abstract}

\section{1: A very odd restaurant}

To connoisseurs of the British author Douglas Adams and his famous trilogy (in five parts) The Hitch Hiker's Guide to the Galaxy, the name Milliways signifies a lot. For the sake of those who have never heard of the absurdly absent Mr. Adams, HHGTTG or Milliways I will begin this essay by briefly explaining what Milliways is. It is a restaurant. A restaurant that is situated at the end of the universe. The phrase the end of the universe does not, however, point to any physical location (that would be impossible since the universe, if cosmologist and astro-physicists are to be believed, seems to be shaped like a doughnut and doughnuts have no ends) but rather to the peculiar fact that the restaurant is the result of a combination of advanced dabbling with the space-time continuum and risk-willing money seeking out new possibilities in the catering business. The truth is that Milliways is build on the fragmented remains of an eventually ruined planet which is enclosed in a vast time bubble and projected forward in time to the precise moment of the End of the Universe (Adams 1986, p. 217). This is of course, as both the author and probably you will admit, impossible. To this you can add a string of other impossibilities that hums around Milliways like pigs with new-grown wings around mud. One impossibility being the fact that you just have to place a penny in a savings account before leaving your own place and time, and when you seconds later arrive in the future, it will have accumulated enough interests to enable you to pay the horrendous cost of a meal at Milliways. All this forms the background for one of the most recognized advertisement slogans in the galaxy: If you've done six impossible things this morning, why not round it off with breakfast at Milliways, the Restaurant at the End of the Universe (ibid., p. 217).

The reason that Milliways comes to mind when faced with the task of reflecting upon the challenges of teaching and thinking bioethics is this: Just as Milliways in many ways is an impossible idea that carries with it a certain poetic beauty and truth, so is the concept of both doing and teaching bioethics in the 21. Century a sort of poetic enterprise full of almost insurmountable challenges, but none the less an enterprise which makes the world a place just a little more interesting to spend a lifetime in. And since one of the most difficult challenges within the field of bioethics is to pass on to others what little one may have grasped oneself, teachers of bioethics, as did the builders of Milliways, set themselves a goal that is not easily obtained. All teaching is faced with didactical problems and questions and within bioethics, which in its core is a multi-disciplinary research area, they seem to multiply like concerned bioethicists around a breakthrough in stem-cell research. 
This essay will describe some of these problems, beginning by pointing out that the problems of teaching bioethics may be very different from building a restaurant at the end of the universe, but by no means smaller. There will be no clear-cut answers to the challenges described. Not that I would not give them to you, if I had them, mind you. But I don't. All I have is a limited experience and a series of trial and error attempts that have taught me that successful teaching demands three things. A: A deep fascination of the subject, B: A sonar-like receptivity to the prerequisitions of the students and C:A firm belief in the value of attempting to contribute to the complexification of existence for other human beings. I will, however, occasionally, mention if I have made any experiences that might benefit others.

\section{2: Five challenges}

This chapter discusses five challenges that surfaces time and time again when teaching and researching is the subject. In fact it seems that the challenges for teaching the subject of ethics are very closely connected to the challenges within the discipline of ethics itself. Whether this is true in general of teaching, I do not know. But I do know that as ethics is not a subject that you can learn to apply to problems in the same way that you can be taught to dissect a frog. Ethics is something you grasp with your existence. And that probably goes a long way in explaining why the problems of doing bioethics constantly surface when you try to teach it. The challenges will be viewed both from a research and an educational perspective. It should be noted from the outset that I strictly apply the ACOSTOE-methodology throughout the whole article. ${ }^{1}$

\section{1: The lack of common educational background}

There is an obvious lack of educational common ground between people doing bioethics. All are trained experts in some field: Medicine, philosophy, theology, law, anthropology, genetic engineering, molecular biology etc., but very few have extended university based training in bioethics. The explanation for this is that such training does not exist. Bioethics is something you do on the basis of your expertise within a certain field.This means that people doing bioethics are usually highly academically qualified within some aspects of bioethics and more or less autodidact within others. One of the more striking consequences of this is that people trained in the natural sciences tend to give the technical or scientific part of the problem a lot of attention where as people trained in the humanistic tradition $^{2}$ tend to be more interested in getting a broader perspective on the problem and see it as connected to other problems.

It takes a lot of time and education to cross such barriers. Barriers as these that are a consequence of former education have a tendency to make the two sides suspicious towards one another. People coming from the natural sciences are often seen as some kind of utilitarians, which is a term that in large parts of the humanistic tradition has the same function as a sign saying "Unethical Thinking Ahead - Proceed at own Risk ", whereas people coming from the humanistic tradition has the same effect on natural scientists as the proverbial red flag on bulls, as they are seen as hopeless idealists with no understanding of the problems and solutions of the real world. This conflict is often hidden behind a pronounced will from both sides to draw the perspective of the other side into the debate, but at the end of the day usually very little has changed and the arguments stemming from your own perspective is given the most if not all importance. ${ }^{3}$

The didactic challenge in this connection is mainly to be able to make students interested in subjects, methodologies and ways of thinking and arguing that they usually do not concern themselves with. As a teacher you have to make students of medicine and natural science interested in and capable of grasping rather complex philosophical concepts such as "person", "autonomy", "integrity" and "ethics" and somehow include them in their argumentation. Teaching e.g. philosophers is not much easier though, since they have to grasp and understand the consequences of concepts like "genes", "cloning", "embryonic stem ce 1 " and "epigenetics". Nevertheless, this is crucial in demonstrating to the students the rather limited perspective that they inevitably will be discussing bioethical problems from, thus enabling them to evaluate their own arguments.

The way to do it is not to tell them that this is important. Nothing is more demotivating than when the teacher has to tell you that something is important. As teachers we should be able to get that point through simply by teaching the subject, since we ourselves hopefully find it important. I admit it is not easy to do this, but in my experience it helps a lot, if you allow the students to understand why you yourself find this so enormously important and show them how knowledge and emotionality are bound together.

\section{2: A plurality of values}

There is no consensus about the values that should guide bioethical decisions. No list of true and false results and no way of scientifically deciding what is good and what is evil. In a democratic, secularist and pluralistic society as Denmark is (at least to some degree), it is impossible to find common values to use as a foundation for bioethical decision-making. That is, unless we are satisfied with a number of different values that are kept at a very vague level and thus begging the question when they get into conflict. Example: Which values should guide us when we have to decide whether genetic diagnostics should be offered as 
a public health service to all pregnant couples either before implantation or in the beginning of pregnancy? The respect for the pregnant couple's autonomy, the respect for the embryos, the economical benefits this could result in, the respect for the feelings of those already born with a severe genetically caused handicap, the wisdom of not reducing the human gene-pool in the light of us having no clue of its value in the future etc. etc. (Engelhardt 1996). All these values are to be debated and questioned in public and be available for philosophical scrutiny, but we will still end up with people having different values which all are, if you pursue their origins long enough, irrational or perhaps pre-rational. There is no way to prove that an embryo has any ethical significance, but there is no way to disprove it either.

The real challenge here is to convince students with a background in science that this does not mean that ethics is something purely subjective and silly. Students coming from the humanities are usually used to the idea that the truth might be something we strive towards in some sort of hermeneutical movement, but to science students this seems very unscientific. One way to break down the often very rigid division between science and the rest of the universe that exist in science students is to make them think through what consequences it would have for their personal lives, if they only were allowed to act on a purely scientifically based world-view. It is my experience that this has a sobering effect.

\section{3: No commonly accepted purpose of bioethics}

There is no consensus about the purpose of bioethics. This is quite natural since there is no consensus on the purpose of ethics. I will not give you an elaborated list of the different possibilities that exist within the ethical literature (If one goes into detail, it seems that every ethicist has her or his own view on the matter) but just draw attention to one very large demarcation-line that runs through the ethical landscape as philosophy's version of the Grand Canyon. To some, and I am here referring to people coming mostly from the consequentialist tradition (think of a philosopher as Peter Singer) and the tradition that are sometimes called principle-ethics (think of Beauchamp and Childress and the Georgetown-Mantra), the task of ethics is to solve problems. The ethicist is roughly speaking seen as an expert among others. When you are having trouble with your toilet you call the plumber, and when you have an ethical problem you call an ethicist. This is, with some reservations, the idea behind the multitudes of ethical committees, councils, advisory boards etc. that have broken through the fertile ground of biotechnological progress the past $10-20$ years in a degree that one is tempted to rephrase the famous article by Stephen Toulmin and say that DNA saved the life of ethicists (Toulmin 1982).
On the other hand you have a very diverse group of thinkers, about whom you can say that they have very little in common with the above mentionedl tradition within ethics. I am thinking of people like Iris Murdoch, Emmanuel Levinas, Mary Midgley, and K. E. Løgstrup. They do not see ethics as a way of solving ethical problems. One of the main reasons for this is that if ethics is made into a list of good actions that can be formulated by ethicists and subsequently enacted by others, the whole idea of ethics breaks down. Within this tradition, ethics is a question of responsibility and of acting according to your conscience. Ethics is first and foremost a question of being. Being in situations, being aware of all aspects of them and acting in the right way at the right time and place according to your understanding of your own being and the being of the other. Subsequently one can formulate heuristic principles and do the consequentialistic juggling with factors, but the primary task of ethics is to make people understand that they are responsible creatures (Lindseth 2002). The difference is perhaps best characterized by claiming that the first tradition sees ethics as a tool to solve ethical problems with, a hammer to drive the ethical nail in with, whereas the other tradition sees ethics as a way of looking at a situation from different perspectives, not necessarily solving anything but perhaps clarifying something. The Danish philosopher Ulli Zeitler has phrased it this way:

"Essentially, the task and reasonable expectation of philosophical activity is not to solve problems, although we may advance considerably by clearing up the central concepts, but opening our eyes to previously unconsidered problems. The last function is crucial for giving new directions to future inquiries" Zeitler 1997, p. 39

These different approaches affect the way bioethics is taught too. If you want students to be problem-solvers, you give them the tools to solve problems, which is basically a set of principles that are more or less open to interpretation, ideas about what constitutes good and bad life (joy \& suffering) to be used in consequentialistic algebra, and a firm conviction that doing good is a question of applying you pre-meditated ideas of the good to the situations you encounter. If you want students to be a sort of ethical light-bulbs that might enlighten the complexities of ethical dilemmas, you make them familiar with a range of different ethical positions from the tradition, train them in shifting their perspectives, and tell them it is not a failure that they cannot always do good (unless you are teaching them religious ethics, where this is an excellent point of departure for teaching them about the concepts of original sin and free will).

This seems fairly easy, but one should be aware that the background of the students will influence their 
understanding of what ethics should be.Thus teaching science students to be light bulbs or students of theology to be problem solvers will perhaps prove hard. And in this rough generalization I have not taken into account that you often have students in the same class room who have formed their notion of what ethics should be independently of their studies. A typical class of 25 biotechnology students thus might have 18 students whose pre-understanding of ethics is that it should be clear-cut, technically oriented, sciencebased and problem solving whereas 7 of the students find that ethics should explore the complexities of human existence and evaluation, be based on everyday experiences and not necessarily solve anything. The advantage of this is that the students can learn about different perspectives in ethics directly during class discussions. But at the same time the different interests in the class makes it challenging not to lose any one group of students along the way.

\section{4: How, why and who?}

One thing that is almost painfully clear is that the seemingly innocent question How to teach bioethics is very dependent on the answers to two other questions: Why am I teaching and who am I teaching? The "why«question I have already touched upon. Making clear to oneself what the purpose of teaching bioethics is (or should be) seems like a vital preliminary step to take, if one is to have any success as a teacher. Whether one chooses to educate ethical problem-solvers or problemfinders, one has to choose methods of teaching that are congruent with the educational goals.

But the "who«-question is probably even more important. Basically, the students can be divided into two groups: Those who have had prior training in philosophy and ethics and those who are trained in the natural sciences. This means that the two groups have very different prerequisitions for grasping the problems that arise from biotechnology and that the teacher has to present his or her material in accordance with the level of student-knowledge in the different disciplines that bioethics contain. As mentioned above the groups will also differentiate themselves, thus not being so uniform as perhaps indicated here. But basically you have to teach a multi-disciplinary subject to monodisciplinary students - and this very often has to be done within a rather limited amount of time and on the basis of a limited amount of text material, since bioethics seldom is seen as a core subject. ${ }^{4}$

I believe that there is a lot of staying up all night, drinking too much coffee and hard thinking ahead in trying to answer the question of the didactics of bioethics. One question that could keep you awake for several nights is to figure out what kind of didactical problems one encounters when teaching bioethics within different disciplines (students of law raise their special demands to the teacher, I am sure, just as theological students raise theirs). As an example, I will just mention that one of the main teaching bioethics to students from medicine or the natural sciences is to make the ethics-part of bioethics seem interesting. But when teaching philosophers and theologians the problem seems to be the reverse. They have a high competence-level within ethics and can be expected to find even Immanuel Kant interesting, but they often find the scientific background knowledge hard to grasp and boring. And as the teacher very often has the same educational background as the students, it can be very difficult to present molecular biology in an interesting and catching way to a group of theological students.

One way to seek to solve this problem is to have two teachers in each class - one that is trained in ethics and one that is trained in e.g. molecular biology. Or to at least have teachers with different backgrounds during the course. One thing is to suggest this solution; another is to make it work. My experience is that as a model of teaching it is highly dependent on the personal and didactical qualifications of the teachers and the relationship between them. The methodology has been used at the basic courses in ethics and philosophy of science for the past 5-6 years. For an evaluation of this please see Dich et al. 2005.

Another problem that arises from the fact that students have very different prerequisitions due to their educational background is that it makes it very hard to teach students with different backgrounds at the same time. Gathering a group of interested students from different faculties at the university and then trying to teach them about the ethical problems in connection with genetic engineering is a beautiful idea, but the didactical problems will be enormous. But at the same time it is often the case that bioethics only thrives in such an inter-disciplinary environment, where the presuppositions of both students and teachers are seriously challenged. Although I promised that I would give no solutions to the problems brought fort in this article, I will just state that one way of getting around this problem would be to begin by teaching the students with the same background and bring them to a certain level on the subjects that are unknown to them and then bring the students together afterwards at a common course.

\section{5: The concept of guilt}

The last challenge in teaching bioethics that I will touch upon here is closely related to the problems mentioned in the previous sections. But at the same time it transcends them all and should perhaps rather be seen as the basic challenge, both when teaching and doing bioethics. To explain it, I will begin with a very simple observation: It is very rare that we ask people: Why did you do that? when they have done something that we judge to be ethically good. In other words: There is no need to justify an ethical act. This is basi- 
cally because we all want to be morally good (Well, almost all of us. One has to admit that bastards do exist). But sometimes we find ourselves in situations, where we become unsure about what the ethically right action is. There are three reasons to this doubt.

\subsection{1: Three reasons to be in doubt}

The most common reason for ethical doubt is selfdeception. The problem is not that we do not know what is ethically right, but that we have other reasons and motives that make us do something else. But since we all want to be good, we have to invent some sort of conflict of interests that can be used to legitimize our actions to others and none the least to ourselves. It might be a worrying experience, but it is a good way to stay humble to just once in a while reflect upon the ethical value of one's own arguments regarding e.g. eating meat or not supporting Red Cross or other humanitarian organisations. Part of doing bioethics is precisely to unmask these self-deceptions; a task that admittedly is much more fun when it is not turned against yourself.

Another reason that we might feel lost in a sort of ethical darkness is that we do not have a thorough understanding of the situation. It is a feeling that often creeps in on you, when you are faced with cases from ethical text-books. They usually state very briefly a few facts about the persons involved and then ask you to choose the ethically right action on a matter that means life and/or death to these persons. ${ }^{5}$ The remedy in this situation is not, I repeat is not to grab blindly in the bag with ethical principles in search of something that might fit the situation, but to insist upon gaining a deeper understanding of the situation and the persons involved in the hope that once we understand the situation better, the ethical fog will disappear.

A third reason that we might find ourselves in the dark regarding the right ethical choice in a situation is that it might be one of those situations, where there is no choice or course of action that is ethically good. From many parts of the ethical landscape it will be contested that such situations do not exist. A guess would be that almost all who holds that ethics is basically a human attempt to bring some order into a meaningless universe will say that as ethics is a human construction, we will either have to refine our existing principles/values/calculations or reconstruct them and then the situation will be back to normal. But if ethics is seen as something that humans encounter in their lives with each other as a demand that is put forward by something other than man (God, nature, reality, the universe, life itself), ${ }^{6}$ it is quite possible that we can find ourselves in situations, where there is no possibility to be good. As is perhaps the case in the question of the ethical concerns about stem cell research.

\subsection{2: The ambiguous stem cells}

In the current debate about using embryonic stem cells for research purposes there is a lot of calculating going on, albeit the two ends of the attitude-spectrum as always have clear-cut cases. Thus to those, who hold that the embryo has the same ethical significance as an adult person, embryonic stem cell research is ethically wrong in itself and nothing can justify doing it. At the other end you find those, who view the embryo as nothing more than biological material that can be used as we find fit. To them the only question is, if stem cell research is so promising that it should be funded. But to the rest of us who ascribes ethical significance both to the embryo and to the potential benefits in medical treatment that embryonic stem cell research might cause, it is a lot more difficult.

Some try to weigh the interests, the preferences, the rights and the ethical values that the different groups involved have against each other (embryos vs. future humans who will benefit from the supposed cures that the research will develop). An admittedly very noble occupation, but not very fruitful. Because what we have here is a genuine ethical dilemma. We have two groups of entities that we are ethically obliged to care for and a situation, where caring for one group leads to suffering for the other group. If you insist that the goal of ethics is to find the right or good action, you very often end up doing calculations that say something like: Killing a thousand embryos with $x$-value is wrong because the potential benefits of the research and the likelihood that it will succeed is only of $y$-value. Now this piece of mathematics is clearly dependent on a lot of valuing and that valuing cannot be done in an objective way. How much value we put on an embryo, the healing of a cancer-patient, to what extent we think that the research might be successful and so on is not decided by objective standards, but by who we are as persons embedded in our relations, societies, cultures and religions. So within bioethics you often find very firm convictions about a lot of subjects and a lot of questionable calculations to back them up. It is a little like experts that try to guess the result of a soccer-match on the basis of the two team's statistics. It is all very interesting (if you happen to like soccer), but there are no guaranties that what they predict will be remotely connected to the actual result.

One way of dealing with the problem is to maintain that ethics is a human construction that at least has to try to come to an understanding of the problem that enables people to do the right thing although sometimes on the basis of shaky arguments. Another way is to leave ethics and join politics in the realization that it is a dirty world, where the concepts of good and bad are just relative concepts. But I would like to argue for a third possibility, a possibility that means using the word guilt - a word that is mysteriously lacking in much of the literature on bioethics. 


\subsection{3: Guilt as a basic condition}

To humour me, please let us, at least for now accept that there may be ethical dilemmas - as for instance embryonic stem cell research - where there is no way of acting unambiguously good. How are we then to decide what to do? We can always go back to our struggling to be good and try to figure out a way, in which we can show that what we do is the ethically good thing in the situation (or at least the lesser evil). Indeed that is what the large majority of ethical councils, advisory boards and committees have been doing the last couple of years. ${ }^{7}$ But perhaps we could try to accept that ethics, and especially bioethics, is not so much about being and doing good, but about taking care of others and then ask the question: What kind of guilt can I live with?

To use the concept of guilt in the current bioethical discussion is possibly the most impossible impossibility that I have encountered yet within the business of doing and teaching bioethics. ${ }^{8}$ This could of course be seen as a sign that I should stop using it, since it is needless and stupid. Although I cannot rule out that possibility completely, I will try very briefly to state another reason, why it is so difficult to bring it in to the class room and the discussion and try to explain what could be gained from reflecting on bioethics with the possibility in mind that being human is being guilty.

I see three main reasons why the concept of guilt is so unpopular within contemporary secular bioethics. First of all it has religious connotations. Being guilty in an ethical sense simply sounds a little too much like being a sinner. And since the idea of a god in front of whom humans might be judged as sinners, has no place in a secular society, the notion of being guilty, especially when that guilt, as in the case of ethical dilemmas, cannot be avoided, seems wrong. Instead of taking upon us the responsibility for our actions, we excuse ourselves by pointing to the fact that we, as in the case of embryonic stem cell research, could not avoid harming someone and that the only guilty part in the whole question must be the universe that is created in such a way that these kinds of dilemmas arise. And since we do not believe in any sort of creator either, it does not make much sense to talk about guilt in connection with a universe that can be fully understood within the natural sciences as one big coincidence, so we sort of just forget about the matter, while telling each other that doing what we believe is the lesser evil, constitutes the ethical good action in the situation. In other words: It seems that it is impossible to talk about guilt in the ethical sense, because it is to closely associated with a religious way of thinking.

Another reason that guilt, if it were a person, would be sitting all alone at the back of the class room in a class on bioethics, is that from the "Ethics as a tool«perspective the concept of guilt seems very unproductive. From a psychological point of view guilt can be seen as a negative inhibiting factor that prevents people from living fulfilling lives, where they have the energy and lust for life to make them able to help others. ${ }^{9}$

The third and most important reason why the concept of guilt is so totally absent from the current debate $^{10}$ is that we have no idea of how to handle it. Guilt between living persons is perhaps the least difficult problem. The growing awareness of the need of finding ways to reconciliation between different ethnic groups, is a sign that even within a secularist framework the thought of forgiving is not totally lost. But if we turn to cases where the guilt is accepted as a reality (whether the guilt is caused by a deliberate action, a choice of the lesser evil or just plain carelessness) and the entity harmed is either dead or unable to enter into a dialogue of reconciliation (children, embryos, plants, mentally handicapped, animals etc.) the question becomes: How can we seek forgiveness? Since we have eradicated God as a possibility, it seems that we are faced with carrying the guilt alone. We finally end up in a situation, where we find that we are sort of existentially guilty, because we have chosen (and the reasons are not important at this point) to sacrifice an uncertain number of embryos to the benefit of potential cures of deadly diseases.

\subsection{4: Løgstrup. the concept of guilt and beyond}

This brings us into a situation, where there are three possibilities according to the Danish theologian K. E. Løgstrup. A: We can give up trying to act ethically. Having failed once to live up to our ethical standards, we simply stop trying altogether, either in respect for the victims that we have already created or because we become bitter and cynical from the experience of failing. B:We can deny that we are guilty and blame the evil done on society, nature, upbringing, circumstances, bad luck, misunderstandings, and chance. Only one thing is for sure - it is not our fault. This is, as I have already mentioned, probably the most common way of doing ethics - the ethics of self-deception. C: The third possibility when faced with inevitable guilt is (and this comes as no surprise to those who know that Løgstrup was a theologian) to live on the mercy and forgiveness of God. To trust that God will take care of victims that we have created and that he has forgiven us so that we have the courage to turn our attention away from our own guilt towards the needs of the other (Løgstrup 1972, p. 81).

To Løgstrup then the case is pretty clear. Either you break down, lie to yourself or become a Christian. But perhaps there are ways of dealing with guilt within a philosophical frame-work without having to convert to Christianity. One way, as I mentioned earlier, would be to ask the question: What kind of guilt can I live with? And that question should be posed both at the personal, the communitarian and the societal level. To hold on to the notion that in some cases we 
become guilty in an ethical sense no matter what we do, would change the way bioethics is done and taught in a lot of ways, but I will mention just one: It would make us more humble towards the gigantic powers that biotechnology gives us to change both ourselves and the rest of nature. Being guilty means needing help and perhaps the realization that we need other people to help us carry our burden, would make us more aware of the fact that humans are basically social creatures, created by the relations that they are embedded in. Our lives are lives of inter-dependence, also when it comes to facing up to being guilty. And it would perhaps make us reflect a little more on the need for humility within bioethics, a humility that could be a safe-guard against the roaming visions of biotechnology. ${ }^{11}$ It might be so that the realization that ethics is not a question of securing our own goodness, but a question of understanding the needs of others and the acknowledgement that we, each and every one us, are guilty both in deliberate wrongdoings and in situations where we choose betweens evils, is the best way to secure that we proceed with great care and humility, as we pursue all the gold that allegedly lies at the foot of the biotechnological rainbow.

\section{3: And the answer is: $\mathbf{4 2}$}

Salman Rushdie once wrote that every day asks us the question of the meaning of life and each night we lie like question marks in our beds. Doing and teaching bioethics could be seen in the same way. As I have tried to illustrate above, bioethical thinking and teaching is faced with a lot of challenges that there are no simple answers to. Some of them are implicit in the whole concept of ethics, others are specific to the different contexts that bioethics is to be taught in. Figuring out the answers - or perhaps more correctly: Continuing to wrestle the questions is nevertheless, as I see it, an ethical duty that each and every one of us is obliged to take upon us. ${ }^{12}$ Whether we are teachers and researchers of bioethics or simply humans living in the biotech century (Rifkin 1999) we all have a responsibility to participate in deciding how biotechnology should change our lives.

To some, ethics is a way of making the world rational and controllable. As I think it should be clear by now, I do not agree with this perspective on ethics. I rather see it as a way of discovering how complex and ambiguous our lives are, when we try to understand how, when and why we are ethically committed to each other (and indeed to the rest of nature too). This is, from my point of view, the second most important message to get through to the students while attempting to juggle the other challenges already mentioned in this essay. The most important is a certain amount of humility towards the ability of the human mind to grasp once and for all the ethical difference between good and evil.

Or as it is told in The Hitch-Hiker's Guide to the Galaxy: Once upon a time in a galaxy far far away a group of meta-intelligent beings from another dimension build a computer called Deep Thought to answer the question: What is the meaning of Life, the Universe and Everything? Deep Thought pondered that question for about seven and a half million years and then revealed (much to the bewildering of the descendants of the original designers) that the answer is 42 . This may seem rather disappointing, but according to Deep Thought the problem was (and is) that the question was not put precisely enough. And perhaps the real problem is that the texture of the universe is in such a way that the question and the answer cannot exist at the same time ${ }^{13}$. As soon as they are both known, the universe simply dissolves and is replaced by something even stranger.

This might leave you completely in the dark. But then, on the other hand, you might find some comfort in the belief that the answer to all our questions is 42 , and that all we have to do is to ask our questions about life, the universe and everything in a better way. And that, should we succeed and finally phrase the questions in the right way, reality would just take one step up the bewilderment-ladder and leave us once again in the same sort of interesting, fascinating, worrying and challenging ethical mess that we live in today.

Acknowledgements: An earlier version of this article was published in: How to best teach bioethics. TemaNord 2004:519. The Nordic Committee on Bioethics. The Nordic Council of Ministers. Copenhagen. The author wishes to thank Annemette Fruelund Andersen from The Centre for Bioethics, University of Aarhus for valuable comments to that version.

\section{Literature}

Adams, Douglas (1993): The Hitch Hiker's Guide to the Galaxy. A Trilogy in Four (Five) Parts. Heinemann, London.

Beauchamp,T. L. \& Childress, J. (1994): Principles of Biomedical Ethics. Oxford University Press. Oxford.

Dich T, Hansen T, Christiansen SB, Kaltoft P \& Sandøe P (2005): Teaching ethics to agricultural and veterinary students: experiences from Denmark, in Animal Bioethics. Principles and Teaching Methods. Waageningen Acasdemic Publishers, Waageningen

Engelhardt, H. Tristram, Jr. (1996): The Foundations of Bioethics. Second ed. Oxford University Press. Oxford.

Lindseth, Anders (2002): Løgstrups etikk i et omsorgsperspektiv, in Wolf, Jakob \& Gjerris, Mickey: Spor i sandet. Bidrag til forståelse af K. E. Logstrups forfatterskab. Anis, Copenhagen, p. 63-80.

Løgstrup, K. E. (1972): Norm og spontaneitet. Etik og politik mellem teknokrati og dilletantokrati. Gyldendal, Copenhagen.

Løgstrup, K.E. (1997): The Ethical Demand. University of Notre Dame Press. Notre Dame.

Rifkin, Jeremy (1999): The Biotech Century. How Genetic Commerce Will Change the World. Orion Books, London.

Silver, Lee M. (1998): Remaking Eden. Cloning, Genetic Engineering and the Future of Humankind? Orion Books, London. 
Singer, Peter (1993): Practical Ethics. Cambridge University Press. Cambridge.

Toulmin, Stephen (1982): How Medicine Saved the Life of Ethics, i: Perspectives in Biology and Medicine Vol. 25, The Johns Hopkins University Press and Milton S. Eisenhower Library, Johns Hopkins University, Baltimore, s. 736-750

Zeitler, Ulli (1997): Transport Ethics. An Ethical Analysis of the Impact of Passenger Transport on Human and Non-human Nature. CeSaM. University of Århus.

\section{Notes}

1 Applying COmmon Sense To Own Experiences

2 And in this connection that means all disciplines that comes from outside the natural sciences and reflects upon these.

3 And this is of course a more than simplified picture of reality. There are many bioethicists coming from the natural sciences, who want to broaden the perspective and not just decide on a case-by-case basis and there are many coming from the other tradition that are very aware that doing bioethics involves a lot pragmatic thinking and a will to give a clear and practical advice. As a tendency it is true though, at least from my perspective. But that probably just brings us back to the problem: As we see things, we treat them, and as we have different perspectives on the world, we tend to see it differently

4 More and more ethics is becoming a mandatory subject within the life-sciences, which is a good thing. The amount of credit awarded for taking the classes and therefore the time available for teaching unfortunately still seems rather limited.

5 The cases presented in the appendix in Beauchamp \& Childress are good examples of this. See Beauchamp \& Childress 1994.

6 The Danish theologian K. E. Løgstrup calls his type of ethics ontological to show that the ethical demand is something that we are faced with independently of ourselves. See the appendix article in: Løgstrup 1997.

7 One noteworthy example where the word guilt is almost written is from The President Council on Bioethics (US) where those who support embryonic stem cell research in a report stated that: "In sum, what is owed the embryo is not the same protections, attachments, and rights as a human person; nor is it no respect at all. In making the decision to proceed with research on embryos or cloned embryos, we must do so only for the most compelling reasons - namely, the reasonable expectation that such research will save human lives - and only with eyes open to the moral burden of doing what we believe to be morally best. Even as we establish the biological and moral grounds for using human embryos in certain forms of research, we must face and accept the solemnity of what we propose. Finally, we must proceed with the paradox that accompanies all human suffering and human imperfection in full view: that sometimes we seem morally obligated to do morally troubling things, and that sometimes doing what is good means living with a heavy heart in doing it . The President's Council on Bioethics, Washington, D.C. 2002, Chapter 6. The full report can be read at www.bioethics.gov.

8 Some will say that it is only impossible for those of us who feel the need to talk about guilt to make sense of some of the problems within bioethics. Many bioethicists think that they are doing quite all right without this religiously tainted concept and will probably feel that this is only a problem for some forms of bioethics, not for bioethics in general. But since my point is that many of the problems of dealing with conflicts of interests and other more or less airy attempts to try to distinguish between different entities and their ethical value at their roots all have a fear of the concept of guilt, I will claim that the reluctance towards the concept of guilt is a problem within bioethics in general.

9 It is very important to remember that guilt can have many faces (just as the evils we do to become guilty). If one is obsessed with guilt it quite possibly has the consequences outlined above. But it is not necessarily so that one becomes obsessed with guilt, just because one recognizes that one is guilty. There are both healthy and mentally disturbed kinds of feelings of guilt.

10 It appears within the literature written from the "Ethics as a light-bulb " perspective (and within religiously based bioethics) but is hardly ever discussed within the prevalent "Ethics as a tool" perspective. At the workshop we discussed bioethical problems for 4 days and not once did anybody say anything about what happened to people who did the wrong things - although the idea that they become ethically guilty is pretty obvious.

11 The American bioethicist Lee Silver has given an excellent example of what the future should not be like in his book Remaking Eden, although a lot of the technologies that lead to this kind of future are currently being developed.

12 As an ethicist I am fortunate enough to be allowed making normative claims about the duties of others. That is one of life's great consolations.

13 A couple of the meta-intelligent beings that are very focused on commercializing the answer from Deep Thought, suggest that the question to the answer 42 could be How many roads must a man walk down. But since we all are still here and the answer still seems to be 42 , this cannot be true. 